\title{
New Records of Two Penaeoid Shrimps (Crustacea: Decapoda) from Korean Waters
}

\author{
Jung Nyun Kim*, Jung Hwa Choi, Taeg Yun Oh, Kangseok Hwang, \\ Jong-Bin Kim, Kwang Ho Choi and Dong Woo Lee \\ Fisheries Resources Management Division, National Fisheries Research and \\ Development Institute, Busan 619-705, Korea
}

\begin{abstract}
Two penaeoid shrimps, Hadropenaeus lucasii (Bate, 1881) and Sicyonia truncata (Kubo, 1949), were collected from the northeastern waters of Jeju Island, Korea. These represent the only Korean reports of a member of the genus Hadropenaeus, family Solenoceridae and of a member of family Sicyonidae, respectively. Morphological descriptions and illustrations with a color photograph of each species are given. Korean Penaeoidea presently includes 27 species in three families.
\end{abstract}

Key words: Hadropenaeus lucasii, Sicyonia truncata, Penaeoidea, Decapoda, Korea, New record

\section{Introduction}

Korean penaeoid shrimps comprise 25 species in two families (Kim and Kim, 1997; Cha et al., 2001; Kim et al., 2002; Kim et al., 2003; Kim and Choi, 2003; Kim et al., 2006; Kim et al., 2007). Recently, the number of species reported from Korean waters has been continuously increasing. From the northeastern waters of Jeju Island, two species of penaeoid species, Hadropenaeus lucasii (Bate, 1881) and Sicyonia truncata (Kubo, 1949), previously unreported from Korea, were collected by bottom otter trawl at a depth of $77 \mathrm{~m}$. These are new members of the Korean carcinological fauna as well as the only known Korean member of the genus Hadropenaeus and the family Sicyonidae, respecttively. Morphological descriptions and illustrations with a color photograph are given for each species.

\section{Materials and Methods}

Specimens examined have been deposited with the Fisheries Resource Management Division, National Fisheries Research and Development Institute (NFRDI). Postorbital carapace length (CL) is used as the standard length of the specimens for measurements, and the terminology primarily follows Pérez Farfante and Kensley (1997).

*Corresponding author: crangonk@nfrdi.go.kr

\author{
Results and Discussion \\ Family Solenoceridae \\ Hadropenaeus lucasii (Bate, 1881) \\ (New Korean name: \\ Maekkeun-daerong-suyeom-saewoo) \\ (Figs. 1, 3A)
}

\section{Restricted synonymy}

Solenocera lucasii - Bate, 1881:185 [type locality: Kai Island, Indonesia].

Pleoticus lucasii: Bate, 1888: 227, pl. 42, fig. 4.

Hymenopenaeus lucasii - Kubo, 1949: 213, figs. 8B, 20Q, 27K-N, 66O, P, 72C, I, 80H, 91, 92A-C.

Hymenopenaeus lucasi - Crosnier, 1978: 115, figs. 37f-h, 39c, 43a, 44.

Hadropenaeus lucasii - Pérez Farfante, 1977: 327, figs. 9, 16, 44C, 53-55; Hayashi, 1986: 43, 232, unnumbered fig.; 1992: 171, figs. 93, 94, 97., Miyake, 1998: 5, pl. 2, fig. 1; Dall, 1999: 560, fig. 5; 2005: 413.

Material examined: Southeastern waters of Jeju Island, $77 \mathrm{~m}$, bottom otter trawl, October 2, 2008, one male (CL 8.4 mm), NFRDI-CR 20100906-1.

Description: Carapace almost entirely glabrous, with some pubescence in rostral and dorsoanterior area (Fig. 1A). Rostrum reaching as far as first segment of antennular peduncle; upper margin straight with seven teeth including epigastric tooth; epigastric tooth 


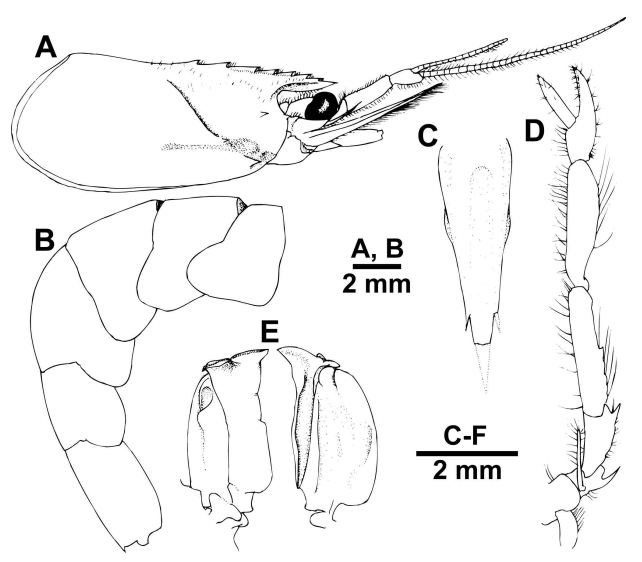

Fig. 1. Hadropenaeus lucasii (Bate, 1881), male (CL $8.4 \mathrm{~mm}$ ) from the northeastern water of Jeju Island. A, carapace and cephalic appendages, lateral; B, abdomen, lateral; $\mathrm{C}$, telson, dorsal; $\mathrm{D}$, right first pereopod, lateral; E, right piece of petasma, dorsal (left) and ventral (right).

and first rostral tooth separated by equal intervals (Fig. 1A). Postorbital, antennal, hepatic and branchiostegal spines well defined. Cervical sulcus almost reaching middorsum; hepatic sulcus shallow (Fig. 1A). Antennular flagella longer than carapace length, upper flagellum subcylindrical (Fig. 1A). Abdomen with well-developed middorsal carina on third to sixth somites, rounded on third somite, keel like on fourth to sixth somites (Fig. 1B). Telson with a pair of lateral immovable spines (Fig. 1C). First pereopod with long spine on basis and ischum, small spine at mid-length of merus (Fig. 1D). Second pereopod with long spine on basis. Fourth and fifth pereopods with anteromedian small spine on each coxa. Petasma with ventral costa free from heavy sclerotization, platelike terminal part of ventral lobule (Fig. 1E).

Coloration in freshly preserved specimen: Rostrum pinkish blue; carapace red to pink; abdomen light pink dorsally, reddish pink ventrally; appendages red (Fig. 3A).

Distribution: Indo-West Pacific region: Mozambique to Indonesia, northwestern and eastern Australia, Japan to Hawaii and Wallis and Futuna Islands; 121$698 \mathrm{~m}$ (Dall, 2005). Southeastern waters of Jeju Island at $77 \mathrm{~m}$ in this study.

Size: Maximum CL $24.2 \mathrm{~mm}$ in female (Hayashi, 1986).

Remarks: Korean Solenoceridae includes three genera, Solenocera, Haliporides and Hymenopenaeus. Hadropenaeus lucasii is the first representative of its genus from Korea. The genus Hadropenaeus is distinguished from the aforementioned three genera by the following combination of characteristics: (1) the upper antennular flagellum is subcylindrical; (2) the epigastric tooth and the first rostral tooth are separated by an interval equal to or only slightly greater than that between the first and second rostral teeth. Hadropenaeus is represented by four species, occurring mainly in temperate and tropical regions of the world. In East Asian waters, only H. lucasii has been reported.

\section{Family Sicyonidae}

Sicyonia truncata (Kubo, 1949)

(New Korean name: Bawi-saewoo)

(Figs. 2, 3B)

\section{Restricted synonymy}

Eusicyonia truncata - Kubo, 1949: 456, figs. 8M, 48F, 77A, G, 79J, 156E, 158. [type locality: Kumanonada Sea, Japan].

Sicyonia truncata - Starobogatov, 1972: 412, pl. 11, fig. 152a, b; Kensley, 1972: 24, fig. 10C; Burukovsky, 1991: 36, fig. 1 (1-18); Hayashi, 1992: 152, 162, figs. 87d, 88d, 89b, c, 90c; Takeda and Hanamura, 1994: 11, fig. 5a-d; Crosnier, 2003: figs. 21, 22, 107B-D.

Sicyonia laevis - Rathbun, 1906: 908, pl. 20, fig. 7.

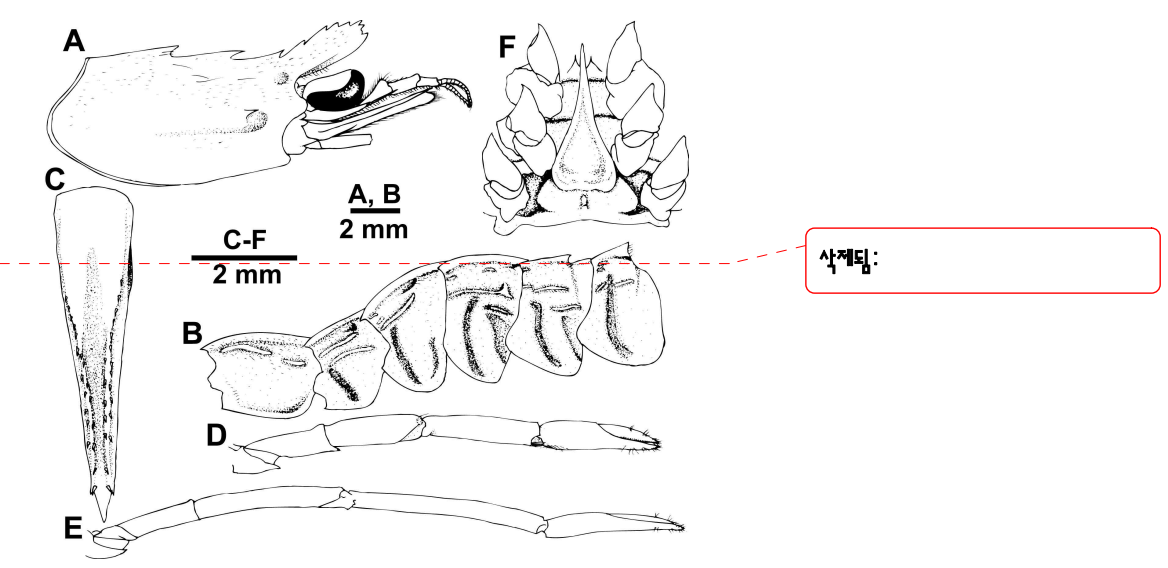

Fig. 2. Sicyonia truncata (Kubo, 1949), female (CL $8.2 \mathrm{~mm}$ ) from the northeastern water of Jeju Island. A, carapace and cephalic appendages, lateral; B, abdomen, lateral; $\mathrm{C}$, telson, dorsal; D, right first pereopod, lateral; E, right second pereopod, lateral; F, thelycum. 
Material examined: Southeastern waters of Jeju Island, $77 \mathrm{~m}$, bottom otter trawl, October 2, 2008, one female (CL $8.2 \mathrm{~mm}$ ), NFRDI-CR 20100906-2.

Description: Body tomentous (Fig. 2A, B). Rostrum subrectangular in lateral view, directed upward at angle of $30^{\circ}$, extends little beyond distal end of first antenular segment, distal depth three times as long as length, with one tooth at distoventral angle, six teeth on dorsal margin (Fig. 2A). Postrostral carina sharply defined, reaching to posterior margin of carapace, bears two teeth, anterior tooth located at $1 / 3$ of carapace and posterior tooth at $2 / 3$; infraorbital lobe rounded distally, lacking spine; hepatic spine distinct (Fig. 2A). Abdomen dorsally carinated; each carina of first two somites with acute spine anteriorly, that of sixth somite ending in sharp spine directed backward, those of first four somites grooved dorsally and incised posteriorly; pleura of first four somites rounded ventrally, that of fifth somite armed with spine projecting backward (Fig. 2B). Telson with pair of lateral immovable spines subterminally, seven or eight small spines dorsally 11 or 12 small spines dorsolaterally (Fig. 2C). First pereopod with long spine on basis and ischum (Fig. 2D). Second pereopod with small spine on basis, without spine on ischum (Fig. 2E). Third pereopod without spine on basis and ischum. Thelycum consists of two closely set flat plates, anterior plate inverted funnel like with sharply pointed long apical spine, though without notch on each lateral rim; posterior plate with median small carina; no sulcus between anterior and posterior plates (Fig. 2F)

Coloration in freshly preserved specimen: Generally reddish pink; posterovental parts of carapace and first to fifth abdominal somites whitish pink; pereopods red; pleopods and uropods whitish brown (Fig. 3B).

Distribution: Indo-West Pacific region: South Africa, Madagascar to Indonesia, NE Australia, Fiji, Tonga, New Caledonia, Vanuatu, Japan to Hawaii; $125-510$ $\mathrm{m}$ (Crosnier, 2003). Southeastern waters of Jeju Island, at $77 \mathrm{~m}$ in this study.

Size: Maximum CL $13.9 \mathrm{~mm}$ in female (Crosnier, 2003)

Remarks: In Korea, the superfamily Penaeoidea contains two families, Penaeidae and Solenoceridae. Sicyonia truncata is the first member of the family Sicyoniidae recorded from Korea. The family is easily distinguishable from the Penaeidae and Solenoceridae by its rigid and stony integument and

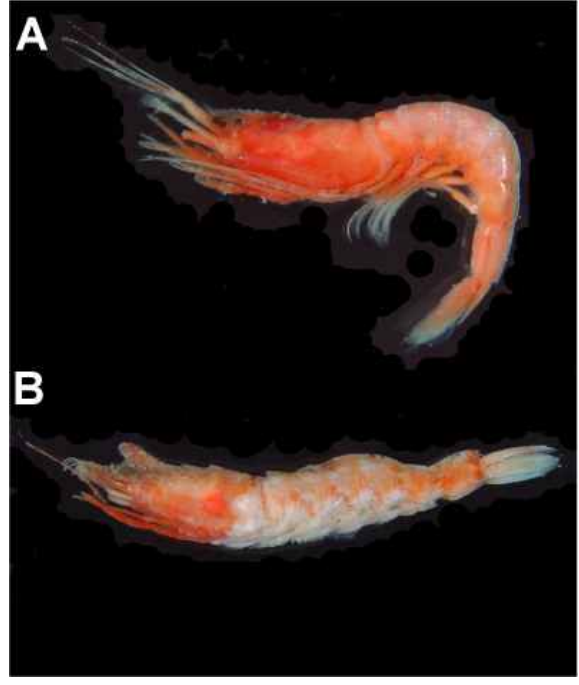

Fig. 3. Two penaeoid shrimps from Korea.

A, Hadropenaeus lucasii (Bate, 1881), male (CL 8.4 $\mathrm{mm}$ ) from the northeastern water of Jeju Island; B, Sicyonia truncata (Kubo, 1949), female (CL $8.2 \mathrm{~mm}$ ) from the same locality.

uniramous third to fifth pleopods, lacking endopods. Sicyoniidae consists of only one genus Sicyonia which contains 54 species worldwide. Fifteen species have been reported from East Asian waters. Of these, $S$. truncata differs from East Asian congeners by the following combination of characteristics: (1) the middorsal carina of the carapace has two teeth (Fig. $2 \mathrm{~A})$; (2) the rostrum is not convergent distally and is truncate in lateral view, and the distal depth of the rostrum is three times the rostral length (Fig. 2A); (3) the infraorbital lobe is rounded distally and lacks a spine (Fig. 2A); (4) a tooth is present on the dorsoanterior of the second abdominal somite (Fig. $2 \mathrm{~B}$ ); and (5) the pleon of the fifth abdominal somite has a tooth posteroventrally (Fig. 2B).

\section{Acknowledgments}

This work was funded by the National Fisheries Research and Development Institute (RP-10-FR-036).

\section{References}

Bate CS. 1881. On the Penaeidea. Ann Mag Nat Hist (5) 8, 169-196, pls. 11, 12.

Bate CS. 1888. Report on the Crustacea Macrura collected 
by H.M.S. Challenger during the years 1873-76. Report on the Scientific Results of the Voyage of the H.M.S. Challenger during the Years 1873-76, Zool 24, 1-942, pls. 1-150.

Burukovsky RN. 1991. New and rare species of shrimps from the South-West part of the Indian Ocean. Zool Zh 70, 36-41.

Cha HK, Lee JU, Park CS, Baik CI, Hong SY, Park JH, Lee DW, Choi YM, Hwang K, Kim ZG, Choi KH, Sohn H, Sohn MH, Kim DH, and Choi JH. 2001. Shrimps of the Korean Waters. National Fisheries Research and Development Institute, Busan, 1-188.

Crosnier A.1978. Crustacés décapodes pénéides Aristeidae (Benthesicyminae, Aristeinae, Solenocerinae). Faune Madagascar 46, 1-197.

Crosnier A. 2003. Sicyonia (Crustacea, Decapoda, Penaeoidea, Sicyoniidae) de I'Indo-ouest Pacifique. Zoosystema 25, 197-348.

Dall W. 1999. Australian species of Solenoceridae (Penaeoidea: Decapoda). Mem Queensland Mus 43, 553-587.

Dall W. 2005. The Penaeoidea (Crustacea: Decapoda) of the Norfanz Cruise. Mem Queensland Mus 51, 407-422.

Hayashi K. 1986. The Penaeoidea and Caridea. In: Decapod Crustaceans from Continental Shelf and Slope around Japan, Baba K, Hayashi K and Toriyama M, eds. Japan Fisheries Resource Conservation Association, Tokyo, 38-163, 232-279.

Hayashi K. 1992. Dendrobranchiata Crustaceans from Japanese Waters. Seibutsu Kenkyusha, Tokyo, 1-300.

Kensley BF. 1972. Shrimps and Prawns of South Africa. South African Museum, Cape Town, 1-65.

Kim JN and Choi JH. 2003. Two new records of decapod crustaceans in Korea. J Fish Sci Tech 6, 203-208.

Kim JN, Choi JH, Kim ST, Cha HK and Hong SY. 2002. Three penaeid species (Crustacea, Decapoda, Penaeidae) from the southeastern coast of Korea. J Fish Sci Tech 5, 235-244.

Kim JN, Choi JH, Kim DH, Cha HK, Kong YG, Lee CH and Han CH. 2003. Two penaeid shrimps (Crustacea, Decapoda) from Jeju Island, Korea. J Fish Sci Tech 6,
88-96.

Kim JN, Choi JH, Kim JB and Kim YS. 2006. Five shrimp species of the genus Solenocera (Crustacea: Decapoda: Solenoceridae) in Korea. J Korean Fish Soc 39 (Spec Iss), 242-251.

Kim JN, Choi JH, Choi KH, Kim ST and Choi YM. 2007. Two penaeoid shrimps (Crustacea: Decapoda) new to Korean waters. J Fish Sci Tech 10, 200-204.

Kim HS and Kim W. 1997. Order Decapoda. In: List of Animals in Korea (Excluding Insects), Korean Society of Systematic Zoology, Seoul, 212-223.

Kubo I. 1949. Studies on the penaeids of Japanese and its adjacent waters. J Tokyo Coll Fish 36, 1-467.

Miyake, S. 1998. Japanese crustacean decapods and stomatopods in color. Vol. I. Macrura, Anomura and Stomatopoda. Hoikusha, Oksaka, 3rd printing, 1-261.

Pérez Farfante I. 1977. American solenocerid shrimps of the genera Hymenopenaeus, Haliporoides, Pleoticus, Hadropenaeus new genus, and Mesopenaeus new genus. Fish Bull 75, 261-346.

Pérez Farfante I and Kensley B. 1997. Penaeoid and sergestoid shrimps and prawns of the world - keys and diagnoses for the families and genera. Mém Mus Natn Hist Nat 175, 1-233.

Rathbun MJ. 1906. The Brachyura and Macrura of the Hawaian Islands, Bull US Fish Comm 23, 827-930, pls. 1-4.

Starobogatov YI. 1972. Peneidy (Sem. Penaeidae Crustacea Decapoda) Tonkingskogo Zaliva, in Fauna Tonkingskogo zaliva i usloviya ee suchchestvovaniya issledovaniya fauny Morey. Isdatelstvo "Nauka" Leningrad 10, 359-415, pls. 1-11.

Takeda M and Hanamura Y. 1994. Deep-sea shrimps and lobsters from the Flores Sea collected by the RV Hakuho-Maru during KH-85-1 cruise. Bull Nat'l Sci Mus ser A (Zool) 20, 1-37.

(Received 6 September 2010; Revised 19 October 2010; Accepted 5 December 2010) 